\title{
Saccharothrix violaceirubra sp. nov., isolated from soil and plant litter
}

\author{
Correspondence \\ Misa Otoguro \\ otoguro-misa@nite.go.jp
}

\author{
Misa Otoguro, ${ }^{1}$ Tomohiko Tamura, ${ }^{1}$ Ken-ichiro Suzuki ${ }^{1}$ \\ and Masayuki Hayakawa ${ }^{2}$
}

${ }^{1}$ NITE Biological Resource Center (NBRC), Department of Biotechnology, National Institute of
Technology and Evaluation (NITE), 2-5-8 Kazusakamatari, Kisarazu, Chiba 292-0818, Japan
${ }^{2}$ Division of Applied Biological Sciences, Interdisciplinary Graduate School of Medicine and
Engineering, University of Yamanashi, 4-3-11 Takeda, Kofu, Yamanashi 400-8511, Japan

Two strains of nocardioform actinomycetes, isolated from soil and plant litter in Yamanashi prefecture, Japan, showed substrate mycelium with purple to dark-red colours. 16S rRNA gene sequence analysis indicated that the organisms belonged to the family Actinosynnemataceae and were related closely to Saccharothrix strains (96.7-98.0\% sequence similarity). The isolates contained MK- $9\left(\mathrm{H}_{4}\right)$ as the predominant menaquinone, meso-diaminopimelic acid, galactose as the diagnostic whole-cell sugar and phosphatidylethanolamine as the predominant polar lipid. Based on a combination of cultural, physiological and chemotaxonomic properties, in addition to the phylogenetic analysis and DNA-DNA hybridization data, we propose a novel species, Saccharothrix violaceirubra sp. nov., for these strains, with the type strain $\mathrm{YU} 692-1^{\top}$ (=NBRC $102064^{\top}=$ KCTC $\left.19326^{\top}\right)$.
The genus Saccharothrix was first described by Labeda et al. (1984) for actinomycete strains that were characterized by nocardioform mycelia and rod-shaped spores, with mesodiaminopimelic acid (meso- $\mathrm{A}_{2} \mathrm{pm}$ ) in the cell wall and with galactose and small amounts of mannose in whole-cell hydrolysates. Menaquinone MK-9 $\left(\mathrm{H}_{4}\right)$ and phosphatidylethanolamine (phospholipid type II) are contained.

In recent years, several Saccharothrix strains have been transferred to other new taxa, including the genera Lentzea (Yassin et al., 1995), Lechevalieria (Labeda et al., 2001), Goodfellowia (Labeda \& Kroppenstedt, 2006), Crossiella (Labeda, 2001) and Umezawaea (Labeda \& Kroppenstedt, 2007). As a result, the genus Saccharothrix currently includes nine species.

During a screening of actinomycetes, strains YU 692-1 ${ }^{\mathrm{T}}$ and YU 724-61, which exhibited synnemata and rodshaped spores, were isolated from soil and plant litter in Japan, respectively. These isolates were subjected to polyphasic taxonomy, including phylogenetic analysis, chemotaxonomy, DNA-DNA relatedness and cultural and physiological properties. On the basis of these characteristics, including their characteristic colony colour,

Abbreviations: meso- $\mathrm{A}_{2} \mathrm{pm}$, meso-diaminopimelic acid; SEM, scanning electron microscopy.

The GenBank/EMBL/DDBJ accession number for the 16S rRNA gene sequence of Saccharothrix violaceirubra $Y \cup 692-1^{\top}$ is AB284261.

A scanning electron micrograph of the synnemata of strain $Y \cup 692-1^{\top}$ is available with the online version of this paper. the strains were accommodated in the genus Saccharothrix. Accordingly, we propose the name Saccharothrix violaceirubra sp. nov. for strains YU 692-1 ${ }^{\mathrm{T}}$ and YU 724-61.

Strains YU 692-1 ${ }^{\mathrm{T}}$ and YU 724-61 were isolated from samples of soil and plant litter in Yamanashi prefecture, Japan, using humic acid/vitamin (HV) agar (Hayakawa \& Nonomura, 1987) supplemented with cycloheximide $\left(50 \mathrm{mg} \mathrm{l}^{-1}\right)$ and nalidixic acid $\left(20 \mathrm{mg} \mathrm{l}^{-1}\right)$. Morphological features of the strains grown on YS medium ( 2 g yeast extract, $10 \mathrm{~g}$ soluble starch and $15 \mathrm{~g}$ agar $\mathrm{l}^{-1} ; \mathrm{pH}$ 7.3) or HV agar were observed by light and scanning electron microscopy (SEM) (model JSM-6060; JEOL). Preparation of samples for SEM was done as described previously (Tamura et al., 1994).

Cultural, physiological and biochemical characteristics were examined by using methods described previously (Gordon et al., 1974; Shirling \& Gottlieb, 1966; Williams et al., 1983). $\mathrm{A}_{2} \mathrm{pm}$ isomers, whole-cell sugar patterns, fatty acid compositions, isoprenoid quinones and polar lipids were analysed as described by Tamura et al. (1994). Genomic DNA was obtained by using the method of Saito \& Miura (1963). The $\mathrm{G}+\mathrm{C}$ content of the DNA was determined by HPLC as described by Tamura et al. (1994). DNA-DNA hybridization was performed fluorometrically in microdilution wells using photobiotin, as described by Ezaki et al. (1989).

The 16S rRNA gene was amplified by PCR and sequenced following the procedures described by Tamura \& Hatano (2001), using a model ABI PRISM 3100 Genetic Analyzer 
according to the manufacturer's protocol. The 16S rRNA gene sequences obtained in the present study were aligned with sequences of species of the family Actinosynnemataceae with validly published names that were available from GenBank/EMBL/DDBJ by using the MEGA (Molecular Evolutionary Genetics Analysis) version 3.1 (Kumar et al., 2004) and CLUSTAL_X (Thompson et al., 1997) programs. A phylogenetic tree was inferred by using the neighbour-joining tree algorithm (Saitou \& Nei, 1987) and the minimum-evolution and maximum-parsimony methods (Takahashi \& Nei, 2000). The topology of the constructed tree was evaluated by bootstrap analysis with 1000 replicates (Felsenstein, 1985).

The isolates, strains YU 692-1 ${ }^{\mathrm{T}}$ and YU 724-61, produced synnemata and formed spore chains on their aerial mycelia; however, they did not form sporangia. The aerial hyphae were well-developed on yeast extract/malt extract agar (ISP medium 2). The colour of the substrate mycelium was purple to dark red on ISP medium 2 and vivid yellow on ISP medium 6 . White aerial mycelium was observed on ISP media 2 and 4 . These hyphae became septate and gave rise to chains of spores. The formation of branched substrate hyphae and fragmentation into rod-shaped or irregular elements were observed by microscopy. The spores had a smooth surface and were non-motile.

Whole-cell hydrolysates of the two strains contained meso$\mathrm{A}_{2} \mathrm{pm}$, galactose, mannose and rhamnose (wall chemotype III sensu; Lechevalier \& Lechevalier, 1970). The predominant menaquinones of isolate $\mathrm{YU}$ 692-1 ${ }^{\mathrm{T}}$ were MK-9 $\left(\mathrm{H}_{4}\right)$ $(46 \%)$, MK-9 $\left(\mathrm{H}_{6}\right)(22 \%)$ and MK-9 $\left(\mathrm{H}_{8}\right)$ (32\%). The isolates also contained phosphatidylethanolamine (phospholipid type PII sensu; Lechevalier et al., 1977) as a diagnostic phospholipid. The major isoprenoid quinone and phospholipid patterns of the isolates were consistent with those of Saccharothrix australiensis (Labeda et al., $1984)$. The major cellular fatty acids were iso- $\mathrm{C}_{16: 0}(21-$ $23 \%)$, anteiso- $\mathrm{C}_{15: 0}(17-18 \%)$, anteiso- $\mathrm{C}_{17: 0}(8-9 \%)$ and $\mathrm{C}_{17: 1}(8-10 \%)$ (Table 1). The DNA G+C contents of isolates $\mathrm{YU} 692-1^{\mathrm{T}}$ and $\mathrm{YU}$ 724-61 were 70.8 and $70.1 \mathrm{~mol} \%$, respectively.

Phylogenetic analysis of the almost-complete 16S rRNA gene sequences (1432 nt) of isolates $\mathrm{YU} 692-1^{\mathrm{T}}$ and $\mathrm{YU}$ 724-61 revealed that these novel isolates belonged to a cluster of the genus Saccharothrix (Fig. 1). It is clear that strain YU $692-1^{\mathrm{T}}$ formed a distinct phyletic line with Saccharothrix texasensis NRRL B-16134 ${ }^{\mathrm{T}}$. Three treemaking algorithms supported the position of strain YU $692-1^{\mathrm{T}}$ as being consistently in the same clade as Saccharothrix algeriensis NRRL B- $24137^{\mathrm{T}}$, S. australiensis NRRL B-11239 ${ }^{\mathrm{T}}$, Saccharothrix espanaensis NRRL $15764^{\mathrm{T}}$, Saccharothrix mutabilis subsp. capreolus DSM $40225^{\mathrm{T}}$ and S. texasensis NRRL B-16134 ${ }^{\mathrm{T}}$. Sequence similarities between strain YU $692-1^{\mathrm{T}}$ and these most closely related Saccharothrix type strains ranged from $98.0 \%$ (with $S$. australiensis) to $96.4 \%$ (with S. mutabilis subsp. capreolus), whilst strain YU $692-1^{\mathrm{T}}$ exhibited $100 \%$ sequence similarity
Table 1. Cellular fatty acid composition of Saccharothrix violaceirubra strains $\mathrm{YU}_{692-1^{\top}}$ and $\mathrm{YU}$ 724-61 and the phylogenetically most closely related species, Saccharothrix australiensis

Taxa: 1, YU 692-1 $1^{\mathrm{T}}$; 2, YU 724-61; 3, S. australiensis NBRC $14444^{\mathrm{T}}$. Values are percentages of total fatty acids. -, Not detected. Fatty acid identities were determined from the Microbial Identification System software (MIDI Inc.) peak-naming table.

\begin{tabular}{|c|c|c|c|}
\hline Fatty acid & 1 & 2 & 3 \\
\hline iso- $\mathrm{C}_{14: 0}$ & 7.1 & 6.3 & 4.7 \\
\hline iso- $\mathrm{C}_{15: 0} \mathrm{G}$ & 1.3 & 1.7 & 2.4 \\
\hline iso- $\mathrm{C}_{15: 0}$ & 10.4 & 10.6 & 30.3 \\
\hline anteiso- $\mathrm{C}_{15: 0}$ & 17.9 & 17.8 & 4.8 \\
\hline iso- $\mathrm{C}_{16: 1} \mathrm{H}$ & 12.7 & 14.2 & 2.7 \\
\hline iso- $\mathrm{C}_{16: 0}$ & 23.0 & 21.2 & 13.6 \\
\hline anteiso- $\mathrm{C}_{16: 0}$ & - & 0.6 & 3.3 \\
\hline cis $9-\mathrm{C}_{16: 1}$ & - & - & 1.2 \\
\hline $\mathrm{C}_{16: 0}$ 9-methyl & - & - & 10.5 \\
\hline iso- $\mathrm{C}_{17: 1} \omega 9 c$ & 1.6 & 2.0 & - \\
\hline anteiso- $\mathrm{C}_{17: 1} \omega 9 c$ & 1.6 & 2.3 & - \\
\hline anteiso- $\mathrm{C}_{17: 1} \mathrm{C}$ & - & - & 1.0 \\
\hline iso- $\mathrm{C}_{17: 0}$ & 0.8 & 0.7 & 6.5 \\
\hline anteiso- $\mathrm{C}_{17: 0}$ & 8.9 & 8.0 & 11.3 \\
\hline cis9- $\mathrm{C}_{17: 1}$ & - & - & 1.0 \\
\hline $\mathrm{C}_{17: 1} \omega 6 c$ & 7.2 & 7.0 & - \\
\hline $\mathrm{C}_{16: 1} 2-\mathrm{OH}$ & - & - & 1.1 \\
\hline anteiso- $\mathrm{C}_{17: 0} 2-\mathrm{OH}$ & - & - & 1.3 \\
\hline $\mathrm{C}_{17: 0} 2-\mathrm{OH}$ & 0.8 & 1.0 & - \\
\hline
\end{tabular}

to strain YU 724-61. According to sequence similarity values and phylogenetic trees, the isolate were related most closely to the type strain of $S$. australiensis.

Physiological properties of the two isolates and the type strains of phylogenetically related Saccharothrix species are shown in Table 2. The isolates can utilize glucose and sucrose, but dextrin, D-xylose and sorbitol are not utilized. They cannot grow at $37{ }^{\circ} \mathrm{C}$ or in the presence of $4 \%(\mathrm{w} / \mathrm{v})$ $\mathrm{NaCl}$. The strains exhibited good growth at $20-30{ }^{\circ} \mathrm{C}$, with an optimum at $28{ }^{\circ} \mathrm{C}$. In contrast, S. australiensis NRRL $11239^{\mathrm{T}}$, which is physiologically the most closely related species to the isolates, utilizes sorbitol and dextrin, decomposes calcium malate and grows in $4 \% \mathrm{NaCl}$ and at $37{ }^{\circ} \mathrm{C}$. The resistance of strain YU $692-1^{\mathrm{T}}$ to various antibiotics is given in the formal species description below. Some results of antibiotic resistance are different between isolates YU 692-1 ${ }^{\mathrm{T}}$ and YU 724-61 (data not shown).

Strain YU 692-1 ${ }^{\mathrm{T}}$ exhibited DNA-DNA relatedness values of $97-112 \%$ to YU 724-61. Strain YU 724-61 was accordingly identified as belonging to the same species as strain YU 692$1^{\mathrm{T}}$. In contrast, the DNA-DNA relatedness of these isolates to S. espanaensis $\mathrm{NBRC} 15908^{\mathrm{T}}\left(=\mathrm{NBRC} 15066^{\mathrm{T}}\right)$, S. algeriensis NBRC $101915^{\mathrm{T}}$, S. australiensis NBRC $14444^{\mathrm{T}}$, S. mutabilis subsp. capreolus NBRC $12847^{\mathrm{T}}$ and S. texasensis NBRC $14971^{\mathrm{T}}$ was $13.0,11.5,8.0,7.5$ and $7.5 \%$, respectively. 


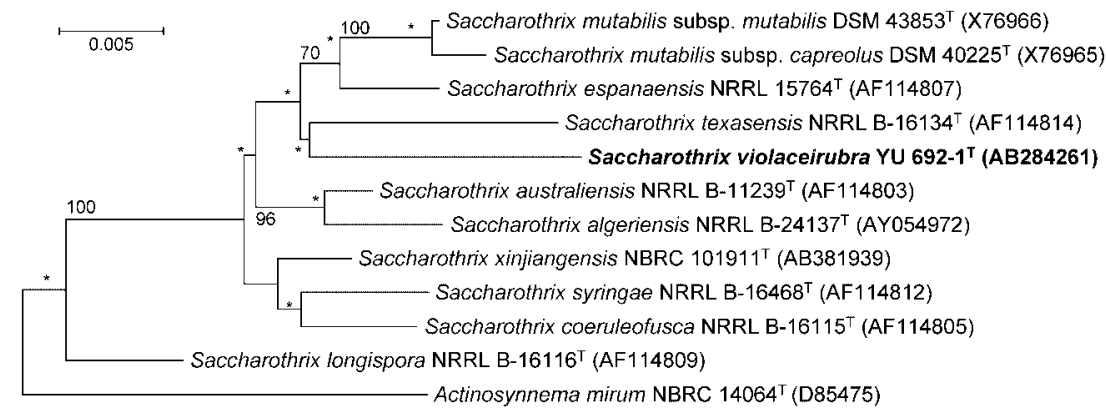

Fig. 1. Neighbour-joining tree (Saitou \& Nei, 1987), based on nearly complete $16 \mathrm{~S}$ rRNA gene sequences for members of the genus Saccharothrix, showing the position of Saccharothrix violaceirubra YU 692-1 ${ }^{\top}$. Actinosynnema mirum NBRC $14064^{\top}$ (GenBank accession no. D85475) was used as an outgroup. Numbers on branches indicate percentage bootstrap values from 1000 replicates (only values $>70 \%$ are shown). Asterisks indicate that the corresponding branches were also recovered in the minimum-evolution and maximum-parsimony trees (Takahashi \& Nei, 2000). Bar, $0.005 K_{\text {nuc }}$.

Table 2. Differential phenotypic properties of isolates $\mathrm{YU}$ $692-1^{\top}$, YU 724-61 and the type strains of phylogenetically related Saccharothrix species

Taxa: 1, strains YU 692-1 ${ }^{\mathrm{T}}$ and YU 724-61; 2, S. australiensis NRRL $11239^{\mathrm{T}}$; 3, S. coeruleofusca DSM $43679^{\mathrm{T}}$; 4, S. espanaensis NRRL $15764^{\mathrm{T}}$; 5, S. mutabilis subsp. capreolus DSM $40225^{\mathrm{T}} ; 6$, S. mutabilis subsp. mutabilis NRRL B-16077 ${ }^{\mathrm{T}}$; 7 S. syringae DSM $43886^{\mathrm{T}} ; 8, S$. texasensis NRRL B-16134 ${ }^{\mathrm{T}}$; 9, S. xinjiangensis AS $4.1731^{\mathrm{T}}$. + , Positive; -, negative; NR, not reported; $W$, weakly positive; $v$, variable. Data for reference species were taken from Labeda (2002) and Hu et al. (2004).

\begin{tabular}{|c|c|c|c|c|c|c|c|c|c|}
\hline Characteristic & 1 & 2 & 3 & 4 & 5 & 6 & 7 & 8 & 9 \\
\hline \multicolumn{10}{|l|}{ Decomposition of: } \\
\hline Hippurate & + & - & - & + & + & + & + & + & NR \\
\hline Hypoxanthine & - & - & - & + & + & + & - & + & NR \\
\hline Starch hydrolysis & - & - & + & - & + & + & + & + & + \\
\hline Tyrosine & + & + & + & - & - & + & + & + & + \\
\hline $\begin{array}{l}\text { Production of nitrate } \\
\text { reductase }\end{array}$ & + & + & - & $\mathrm{W}$ & - & + & - & + & - \\
\hline \multicolumn{10}{|l|}{ Assimilation of: } \\
\hline Citrate & - & - & - & $\mathrm{V}$ & + & + & - & - & - \\
\hline Lactate & - & W & - & + & - & + & - & + & - \\
\hline Malate & - & + & - & + & + & + & + & + & NR \\
\hline \multicolumn{10}{|l|}{ Utilization of: } \\
\hline Arabinose & - & - & + & - & + & + & + & + & + \\
\hline Dextrin & - & + & + & - & + & + & + & + & NR \\
\hline Inositol & - & - & - & - & + & + & - & + & NR \\
\hline Lactose & - & - & + & - & - & + & + & + & + \\
\hline Melibiose & - & - & - & - & + & + & + & + & + \\
\hline Raffinose & - & - & + & - & - & + & + & - & + \\
\hline Rhamnose & - & - & + & - & - & - & + & + & + \\
\hline Salicin & - & - & + & - & + & + & $\mathrm{W}$ & + & NR \\
\hline Sorbitol & - & + & + & - & - & - & - & - & - \\
\hline Sucrose & + & - & + & + & - & + & + & + & + \\
\hline D-Xylose & - & - & + & V & + & + & + & + & + \\
\hline Methyl $\alpha$-D-glucoside & - & - & + & - & - & + & - & + & + \\
\hline \multicolumn{10}{|c|}{ Growth in/at: } \\
\hline $4 \% \mathrm{NaCl}$ & - & + & + & + & + & - & + & - & - \\
\hline $5 \% \mathrm{NaCl}$ & - & - & + & - & + & - & + & - & - \\
\hline $37{ }^{\circ} \mathrm{C}$ & - & + & + & + & + & + & + & + & + \\
\hline $45^{\circ} \mathrm{C}$ & - & + & + & - & + & + & + & - & + \\
\hline
\end{tabular}

Based on 16S rRNA gene sequence data and morphological and chemotaxonomic properties, strains $\mathrm{YU} 692-1^{\mathrm{T}}$ and YU 724-61 belong to the genus Saccharothrix. On the basis of DNA-DNA relatedness and physiological properties, these isolates represent a distinct species in this genus. Accordingly, we propose a novel species, Saccharothrix violaceirubra sp. nov., for isolates YU $692-1^{\mathrm{T}}$ and YU 72461 . The type strain of the species is YU $692-1^{\mathrm{T}}(=\mathrm{NBRC}$ $102064^{\mathrm{T}}=$ KCTC $19326^{\mathrm{T}}$ ).

\section{Description of Saccharothrix violaceirubra sp. nov.}

Saccharothrix violaceirubra (vi.o.la.ce.i.ru'bra. L. adj. violaceus violet; L. adj. ruber -bra -brum red; N.L. fem. adj. violaceirubra violet-red.)

Aerobic and Gram-positive. Forms branched vegetative hyphae and white aerial mycelia, which fragment into ovoid elements. Colonies on ISP medium 2 are purple to dark red in colour. Soluble pigment is not produced. Glucose, maltose, mannose, sucrose and trehalose are utilized. D-Xylose, raffinose, rhamnose, D-ribose, D-mannitol and D-arabinose are not utilized. Negative in tests for starch hydrolysis and calcium malate decomposition. Temperature range for growth is $15-30{ }^{\circ} \mathrm{C}$, with an optimum at approximately $28{ }^{\circ} \mathrm{C}$. Growth occurs in the presence of $0.005 \%$ lysozyme, $0.1 \%$ phenyl ethanol, $0.01 \%$ potassium tellurite, kanamycin $\left(40 \mathrm{mg} \mathrm{ml}^{-1}\right)$, neomycin $\left(40 \mathrm{mg} \mathrm{ml}^{-1}\right)$, leucomycin $\left(2 \mathrm{mg} \mathrm{ml}^{-1}\right)$, lincomycin $\left(16 \mathrm{mg} \mathrm{ml}^{-1}\right)$, novobiocin $\left(1 \mathrm{mg} \mathrm{ml}^{-1}\right)$, streptomycin $\left(20 \mathrm{mg} \mathrm{ml}^{-1}\right)$ and vancomycin $\left(3 \mathrm{mg} \mathrm{ml}^{-1}\right)$. No growth occurs at $37{ }^{\circ} \mathrm{C}$ or in the presence of $4 \% \mathrm{NaCl}$, ampicillin $\left(20 \mathrm{mg} \mathrm{ml}^{-1}\right)$, oxytetracyclin $\left(40 \mathrm{mg} \mathrm{ml}^{-1}\right)$, puromycin $\left(40 \mathrm{mg} \mathrm{ml}^{-1}\right)$ or rifampicin $\left(20 \mathrm{mg} \mathrm{ml}^{-1}\right)$. The major cellular fatty acids are iso- $\mathrm{C}_{16: 0}$, anteiso- $\mathrm{C}_{15: 0}$, anteiso$\mathrm{C}_{17: 0}$ and $\mathrm{C}_{17: 1}$. The $\mathrm{G}+\mathrm{C}$ content of the type strain is $70.8 \mathrm{~mol} \%$.

The type strain is YU $692-1^{\mathrm{T}}\left(=\mathrm{NBRC} 102064^{\mathrm{T}}=\mathrm{KCTC}\right.$ $19326^{\mathrm{T}}$ ), isolated from a soil sample collected in Yamanashi prefecture, Japan. 


\section{References}

Ezaki, T., Hashimoto, Y. \& Yabuuchi, E. (1989). Fluorometric deoxyribonucleic acid-deoxyribonucleic acid hybridization in microdilution wells as an alternative to membrane filter hybridization in which radioisotopes are used to determine genetic relatedness among bacterial strains. Int J Syst Bacteriol 39, 224229.

Felsenstein, J. (1985). Confidence limits on phylogenies: an approach using the bootstrap. Evolution 39, 783-791.

Gordon, R. E., Barnett, D. A., Handerhan, J. E. \& Pang, C. H.-N. (1974). Nocardia coeliaca, Nocardia autotrophica, and the nocardin strain. Int J Syst Bacteriol 24, 54-63.

Hayakawa, M. \& Nonomura, H. (1987). Humic acid-vitamin agar, a new medium for selective isolation of soil actinomycetes. J Ferment Technol 65, 501-509.

Hu, Y.-T., Zhou, P.-J., Zhou, Y.-G., Liu, Z.-H. \& Liu, S.-J. (2004). Saccharothrix xinjigangensis sp. nov., a pyrene-degrading actinomycete isolated from Tianchi Lake, Xinjigang, China. Int J Syst Evol Microbiol 54, 2091-2094.

Kumar, S., Tamura, K. \& Nei, M. (2004). MEGA3: integrated software for molecular evolutionary genetics analysis and sequence alignment. Brief Bioinform 5, 150-163.

Labeda, D. P. (2001). Crossiella gen. nov., a new genus related to Streptoalloteichus. Int J Syst Evol Microbiol 51, 1575-1579.

Labeda, D. P. (2002). The family Actinosynnemataceae. In The Prokaryotes, 3rd edn, pp. 654-668. Edited by M. Dworkin, S. Falkow, E. Rosenberg, K. Schleifer \& E. Stackebrandt. New York: Springer.

Labeda, D. P. \& Kroppenstedt, R. M. (2006). Goodfellowia gen. nov., a new genus of the Pseudonocardineae related to Actinoalloteichus, containing Goodfellowia coeruleoviolacea gen. nov., comb. nov. Int J Syst Evol Microbiol 56, 1203-1207.

Labeda, D. P. \& Kroppenstedt, R. M. (2007). Proposal of Umezawaea gen. nov., a new genus of the Actinosynnemataceae related to Saccharothrix, and transfer of Saccharothrix tangerinus Kinoshita et al. 2000 as Umezawaea tangerina gen. nov., comb. nov. Int J Syst Evol Microbiol 57, 2758-2761.

Labeda, D. P., Testa, R. T., Lechevalier, M. P. \& Lechevalier, H. A. (1984). Saccharothrix: a new genus of the Actinomycetales related to Nocardiopsis. Int J Syst Bacteriol 34, 426-431.
Labeda, D. P., Hatano, K., Kroppenstedt, R. M. \& Tamura, T. (2001). Revival of the genus Lentzea and proposal for Lechevalieria gen. nov. Int J Syst Evol Microbiol 51, 1045-1050.

Lechevalier, M. P. \& Lechevalier, H. A. (1970). Chemical composition as a criterion in the classification of aerobic actinomycetes. Int J Syst Bacteriol 20, 435-443.

Lechevalier, M. P., Stern, A. E. \& Lechevalier, H. A. (1977). Chemotaxonomy of aerobic actinomycetes: phospholipid composition. Biochem Syst Ecol 5, 249-260.

Saito, H. \& Miura, K. (1963). Preparation of transforming deoxyribonucleic acid by phenol treatment. Biochim Biophys Acta 72, 619-629.

Saitou, N. \& Nei, M. (1987). The neighbor-joining method: a new method for reconstructing phylogenetic trees. Mol Biol Evol 4, 406-425.

Shirling, E. B. \& Gottlieb, D. (1966). Methods for characterization of Streptomyces species. Int J Syst Bacteriol 16, 313-340.

Takahashi, K. \& Nei, M. (2000). Efficiencies of fast algorithms of phylogenetic inference under the criteria of maximum parsimony, minimum evolution and maximum likelihood when a large number of sequences are used. Mol Biol Evol 17, 1251-1258.

Tamura, T. \& Hatano, K. (2001). Phylogenetic analysis of the genus Actinoplanes and transfer of Actinoplanes minutisporangius Ruan et al. 1986 and 'Actinoplanes aurantiacus' to Cryptosporangium minutisporangium comb. nov. and Cryptosporangium aurantiacum sp. nov. Int J Syst Evol Microbiol 51, 2119-2125.

Tamura, T., Nakagaito, Y., Nishii, T., Hasegawa, T., Stackebrandt, E. \& Yokota, A. (1994). A new genus of the order Actinomycetales, Couchioplanes gen. nov., with descriptions of Couchioplanes caeruleus (Horan and Brodsky 1986) comb. nov. and Couchioplanes caeruleus subsp. azureus subsp. nov. Int J Syst Bacteriol 44, 193-203.

Thompson, J. D., Gibson, T. J., Plewniak, F., Jeanmougin, F. \& Higgins, D. G. (1997). The CLUSTAL_X windows interface: flexible strategies for multiple sequence alignment aided by quality analysis tools. Nucleic Acids Res 25, 4876-4882.

Williams, S. T., Goodfellow, M., Alderson, G., Wellington, E. M. H., Sneath, P. H. A. \& Sackin, M. J. (1983). Numerical classification of Streptomyces and related taxa. J Gen Microbiol 129, 1743-1813.

Yassin, A. F., Rainey, F. A., Brzezinka, H., Jahnke, K. D., Weissbrodt, H., Budzikiewicz, H., Stackebrandt, E. \& Schaal, K. P. (1995). Lentzea gen. nov., a new genus of the order Actinomycetales. Int J Syst Bacteriol 45, 357-363. 